\title{
PREDICTING THE IMPACTS OF SEA-LEVEL RISE ON THE AMAZON MACROTIDAL MANGROVE COAST
}

\author{
TOMAZ, Raoni - raonibt@gmail.com \\ Universidade CEUMA
}

SANTOS, André - andresantos@ifma.edu.br Instituto Federal do Maranhão / IFMA

BORGES, Helder - helder.borges@ifma.edu.br Instituto Federal do Maranhão / IFMA

\author{
SILVA JUNIOR, Celso Henrique Leite - celso.junior@inpe.br \\ Instituto Nacional de Pesquisas Espaciais / INPE \\ BEZERRA, Denilson da Silva - denilson_ca@yahoo.com.br \\ Universidade Federal do Maranhão / UFMA
}

\begin{abstract}
Brazil has the largest continuous area of mangrove forests in the world, the Amazon Macrotidal Mangrove Coast (AMMC). The objective of the present study is to simulate the response of eastern Amazonian mangroves to sea-level rise, and to produce a vulnerability assessment for this section of the Brazilian coast. We used a spatially explicit model, based on cellular automata and Geographic Information System (GIS) to identify resistance patterns, migration and/or inundation of these mangroves for different events of sea-level rise (SLR). The simulation considers 90 elevation events from $0.00318 \mathrm{~m}$ to $0.2862 \mathrm{~m}$ according to an arithmetic progression of reason $0.00318 \mathrm{~m}$ for the time interval from 2010 to 2100 . The adopted SLR rate was $3.18 \mathrm{~mm} /$ year ( $0.00318 \mathrm{~m} /$ year), this rate corresponds to an average of sea elevation values observed for the Brazilian coast during the mid-twentieth century and early twenty-first century. At the end of the simulation (year 2100), the original mangrove area $\left(4,180 \mathrm{~km}^{2}\right.$ ) was reduced to $2,916 \mathrm{~km}^{2}$, representing a loss of $30.24 \%$. Our simulation also showed significant landward migration of the mangroves, and the modeled loss of the original mangrove area was compensated by a net addition of $301 \mathrm{~km}^{2}$ of new mangroves inland, a net increase of $7.2 \%$ in the total mangrove area $\left(4,481 \mathrm{~km}^{2}\right.$ in 2100$)$. These results suggest that mangrove forests in the AMMC can present a pattern of area increase and migration to the continent from the projected SLR. These findings can help the identification of migration corridors for the Amazonian mangroves and the development of adaptation strategies in face of impending SLR.
\end{abstract}

KEYWORDS: Mangrove forests, Amazonian coast, Climate change, Sea-Level Rise, Computational modeling, Geographic Information System.

PREVENDO OS IMPACTOS DA ELEVAÇÃO DO NÍVEL DO MAR NA COSTA DE MANGUEZAIS DE MACROMARÉS DA AMAZÔNIA

RESUMO: O Brasil possui a maior área contínua de manguezais do mundo, a Costa de Manguezais de Macromarés da Amazônia (CMMA). O objetivo do presente estudo é simular a resposta dos manguezais do leste da Amazônia ao aumento do nível do mar e produzir uma avaliação de vulnerabilidade para este trecho da costa brasileira. Foi utilizado um modelo espacialmente explícito, baseado em autômatos celulares e Sistema de Informações Geográficas (SIG) para identificar padrões de resistência, migração e / ou inundação desses manguezais para diferentes eventos de elevação do nível do mar (ENM). A simulação considera 90 eventos de elevação de 0,00318 m a 0,2862 m de acordo com uma progressão aritmética de razão $0,00318 \mathrm{~m}$ para o intervalo de tempo de 2010 a 2100 . A taxa ENM adotada foi de $3,18 \mathrm{~mm} /$ ano $(0,00318 \mathrm{~m} /$ ano $)$, esta taxa de elevação corresponde a uma média dos valores de elevação do mar observados para a 
costa brasileira em meados do século XX e início do século XXI. Ao final da simulação (ano 2100), a área original de manguezal $(4.180 \mathrm{~km} 2)$ foi reduzida para $2.916 \mathrm{~km} 2$, representando uma perda de 30,24\%. A execução da simulação também mostrou migração significativa do manguezal e a perda modelada da área de manguezal original foi compensada por uma adição líquida de $301 \mathrm{~km} 2$ de manguezais para o interior do continente, um aumento líquido de $7,2 \%$ na área total de manguezais $(4.481 \mathrm{~km} 2 \mathrm{em}$ 2100). Estes resultados sugerem que as florestas de manguezais na CMMA podem apresentar um padrão de aumento de área e migração para o continente a partir da ENM projetada. Essas descobertas podem ajudar na identificação de corredores de migração para os manguezais da Amazônia e no desenvolvimento de estratégias de adaptação frente à ENM iminente

PALAVRAS-CHAVE: Florestas de manguezal, Costa Amazônica, Mudanças Climáticas, Elevação do Nível do Mar, Modelagem Computacional, Sistema de Informação Geográfica.

\section{INTRODUCTION}

Mangroves function as a link between marine and terrestrial ecosystems, playing a vital role in the conservation of biological diversity in tropical and subtropical latitudes (Rog, Clarke and Cook, 2017). They possess highly developed morphological and physiological adaptations, which allow them to exist in conditions of high salinity, extreme tides, strong winds, high temperatures, and muddy, anaerobic soils (Alongi, 2009). Mangroves are also extremely productive ecosystems, home to a large variety of fish, crab, shrimp, and mollusk species (Manson et al. 2005). They also contribute significant quantities of organic matter to coastal ecosystems, and are considered sites of intense biogeochemical processing, potentially impacting the global elemental cycles of carbon and nitrogen (Buillon et al., 2008; Cohen and Lara 2003). In addition, the dense root systems of mangrove forests trap significant amounts of sediment, stabilizing coastlines and preventing erosion from waves and storms (Mazda, Volanski and Ridd, 2007). By filtering out sediments, mangroves also protect coral reefs and seagrass beds from being smothered (Gillis et al., 2014). Together, coral reefs, seagrass beds, and mangrove forests provide a number of ecosystem services, and are among the most valuable natural systems on the planet. The annual value of products and services provided by mangrove forests are estimated to range between $\$ 200,000$ and $\$ 900,000$ per $\mathrm{km}^{2}$ (Wells, 2006).

The warming of the climate system, because of human activities, is unequivocal and unprecedented (IPCC, 2013). This warming is causing changes with widespread impacts on both human and natural systems, on all continents and across all oceans. In coastal regions, these impacts include flooding and shoreline erosion due to sea-level rise (Nicholls, 2004), the intensification of the hydrological cycle (Huntington 2006), and changes in the frequency and intensity of severe storm events (IPPC, 2013).

Of all the effects of climate change, a rising sea level is considered to be the main factor of vulnerability for mangrove forests (Field, 1995). For the present research, the concept of vulnerability adopted is that presented by IPCC (IPCC, 2013), namely: vulnerability is the degree by which a system is likely or unable to cope with adverse effects of climate change, including climate variability and extremes.

Brazil is home to the second largest total area and the largest continuous area of mangrove forests in the world (Spalding, Kainuma and Collins 2010; Nascimento et al. 2013). Therefore, understanding the response of Brazilian 
mangroves to the potential impacts of climate change is a significant challenge. It is almost impossible to gather this information using traditional field-based methods, since mangrove swamps are extremely difficult to access. Fortunately, remote sensing technology provides a promising alternative to solve this problem of accessibility (Green et al., 2000; Howard et al., 2015). Over the last 20 years, remote sensing techniques have demonstrated a high potential to detect, identify, map, and monitor mangrove conditions and changes (see the reviews by Guo et al., 2017; Heumann 2011; Kuenzer 2011; Purnamasayangsukasih et al., 2016). Some examples exist of remote sensing being used exclusively for mapping the extent and distribution of Brazilian mangrove forests (Lacerda, Menezes and Molisani 2007; Nascimento et al., 2013; Souza-Filho 2005; Souza-Filho, 2009). Nevertheless, few studies have attempted to simulate the response of these mangroves to climate change.

In 2009 was proposed a conceptual model of the response of mangrove forests to a possible increase in relative mean sea level induced by global warming (Soares, 2009). According to this model, responses will depend on the rates of sea level rise, rates of sedimentation, the topography of the area, and the availability of suitable areas for mangrove migration landward. In 2010 was formulated a methodology to estimate the degree of combined vulnerability of mangroves and fishing populations to the impacts of climate change in the Paranaguá Estuarine Complex, in southern Brazil. In 2011, a Brazilian study proposed using mangrove reforestation as a tool for protecting the Potiguar Basin (in NE Brazil) from widespread erosion and shoreline instability resulting from climate change and human activities (Dantas, Amaro and Costa, 2011). In 2012, other Brazilian research analyzed pollen, diatoms, and stable isotopes in a sediment core from Ilha do Cardoso mangroves (SE Brazil) and determined that mangrove development ceased after an erosive event associated to the postglacial sea-level rise (SLR) in the region (Pessenda et al., 2012). The mangrove forests existing today in the region developed over the last 2200 years, after the return of the marine coastal line to its current position. In 2013 was discussed multiple approaches using remote sensing and modeling that could simulate mangrove responses to SLR (Bezerra, Amaral and Kampel, 2013). Most recently in 2016, a research (França et al., 2016) combined geomorphological, sedimentological, palynological, and isotope data to analyze the dynamics of mangrove forests in Southeastern Brazil within the context of millennial and secular climatic and sea-level changes. They identified multiple cycles in which Holocene mangrove forests were replaced by tidal flats, following the decline in sea level. They also concluded that the existing mangroves developed over the last 900 years, following a relative SLR. Finally, a survey conducted in 2017 (Fontes et al., 2017) also integrated geomorphological, sedimentological, palynological, and stable isotopic data from mangrove sediment cores to evaluate the compatibility between the Holocene relative sea-level curves proposed for the Brazilian littoral and mangrove dynamics along the fluvial valley of the Jucurucu River (central eastern coast of Brazil). Their results indicate the absence of mangroves during the Holocene high sea-level stand, which occurred about 5,350 years ago.

Although some of these studies relating sea-level changes and mangrove dynamics in Brazil have used remote sensing and/or modeling tools and techniques, none have attempted to predict the impacts of the projected climate and sea-level change on these ecosystems. The objective of the present study is 
to simulate the response of eastern Amazonian mangroves to sea-level rise, and to produce a vulnerability assessment for this section of the Brazilian coast.

\section{STUDY AREA}

Brazil has the second largest mangrove coverage in the world $(13,400$ $\mathrm{km}^{2}$ ), accounting for $8.5 \%$ of the world's total and $50 \%$ of South America's mangrove forests (Spalding, Kainuma and Collins, 2010). The most extensive areas (about $57 \%$ of all mangroves in Brazil) are found in the northern coast, along an extensive, tide-dominated complex of deltaic systems, in the eastern sector of the Amazonian coast. This area, called the Amazon Macrotidal Mangrove Coast (AMMC), covers over $7,000 \mathrm{~km}^{2}$, and form the largest contiguous mangrove system in the world (Nascimento et al., 2013; SouzaFilho, 2005). In this region, the coastline is very jagged with numerous long peninsulas, up to $10 \mathrm{~km}$ wide and extending about $30 \mathrm{~km}$ out to sea (Nascimento et al., 2013). A combination of coastal current patterns and sediment discharge from numerous rivers (including the Amazon) produce a highly dynamic mangrove ecosystem.

This study focuses only on the portion of the AMMC within the Maranhão state, region known as environmental protection area of the Maranhão reentrances - EPA of the Maranhão reentrances (Fig. 1). Here, mangroves reach their maximum seaward development, with widths varying between $26-40 \mathrm{~km}$. This section contains about $72 \%\left(5,414 \mathrm{~km}^{2}\right)$ of the mangroves in the AMMC (Souza-Filho, 2005). This region was transformed into an Environmental Protection Area in 1991 by the Brazilian government due to the occurrence of its expressive area of mangroves. Due to its significant environmental importance in 1993, the EPA of the Maranhão reentrances was also classified as a Ramsar site (wetland of international interest). 


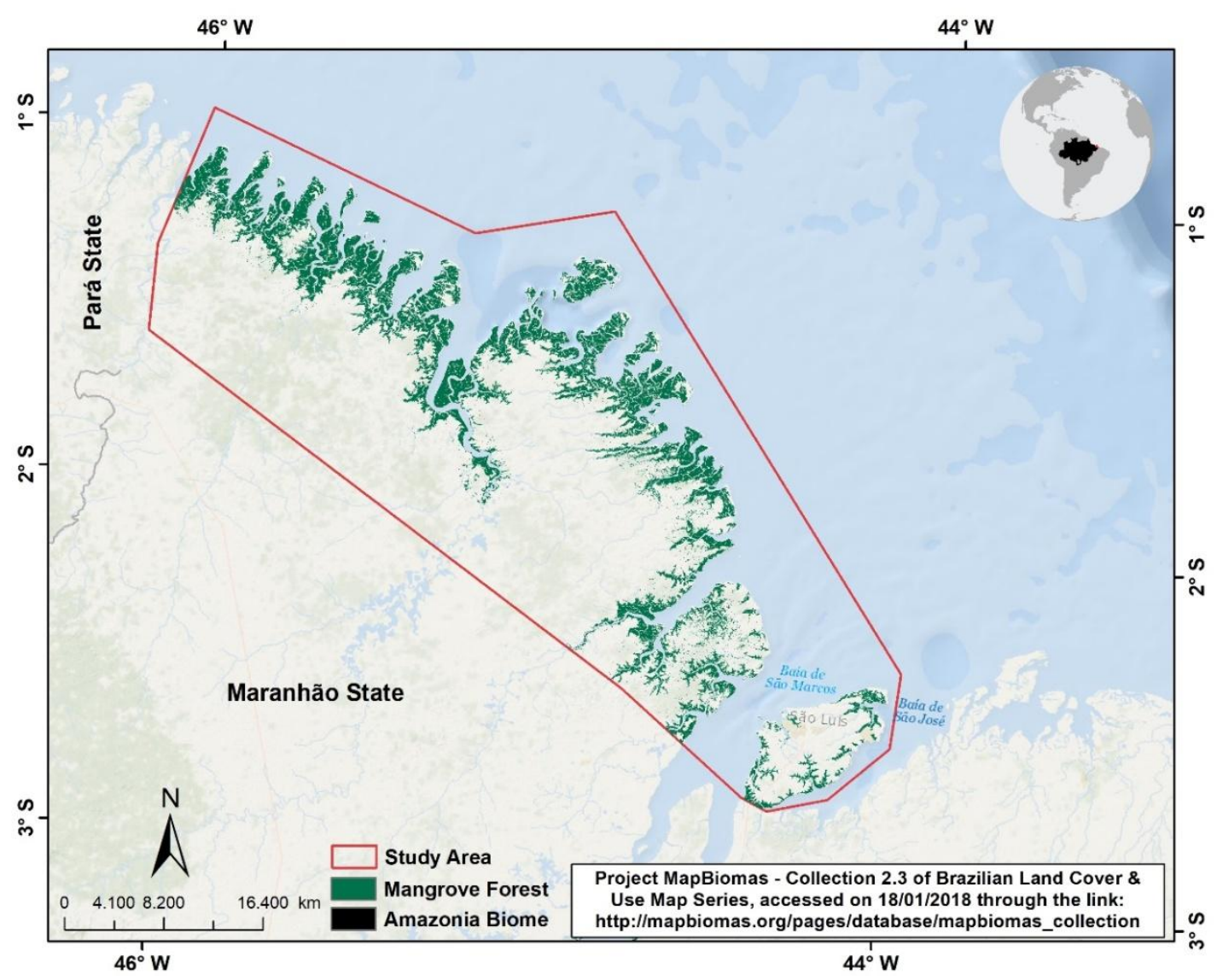

Figure 1 - The study area comprises a section of the AMMC within the Maranhão state.

The meteorological and oceanographic characteristics of the AMMC are quite distinct in comparison with other coastal regions of Brazil. The climate is governed by seasonal changes in the position of the Inter-Tropical Convergence Zone (ITCZ), which is positioned around $14^{\circ} \mathrm{N}$ during the dry season (September-November) and around $2^{\circ} \mathrm{S}$ during the wet season (February-April), when $73 \%$ of the annual precipitation occurs55. Average air temperatures are usually above $25^{\circ} \mathrm{C}$, with little variation between seasons, and annual precipitation ranges from 2300-2800 mm (Moraes et al., 2005).

The continental platform extends some $330 \mathrm{~km}$ into the Atlantic Ocean, and receives the discharge of the Amazon River (16\% of the World's freshwater discharge to the oceans) and dozens of other estuaries, which together supply over 1 billion tons of sediments, nutrients and organic material annually to the coastal zone (Martinelli et al., 1989). The outer shelf is dominated by carbonate sedimentation, both in the form of sand and reefs that have been dated at 17,000 years BP (Milliman and Barreto, 1075). The inner shelf initiates approximately at the $20 \mathrm{~m}$ isobath (15 km away from the coast along the northeast of Pará State), where transgressive siliciclastic marine sands start to occur. The majority of the sand is composed of well-sorted clear quartz (Zembruscki 1971) and suggests a marine origin (Souza-Filho 2005). 


\section{ESTIMATES OF SEA-LEVEL RISE FOR THE BRAZILIAN COAST}

In Brazil there is the Brazilian Panel on Climate Change (PBMC, in Portuguese), official Brazilian institution on climate change issues (for more information: http://www.pbmc.coppe.ufrj.br/en/). In 2017, PBCM released a special report "Impacts, vulnerability and adaptation of Brazilian coastal cities to climate change"

(Available

in: http://www.pbmc.coppe.ufrj.br/pt/publicacoes/relatorios-especiaispbmc/item/relatorio-de-zonas-costeiras?category_id=19). In this report, the PBMC indicates there is no continuous historical series and reliable information about sea elevation to the Brazilian coast, and there are few modeling studies of elevation projections, which undermines any future prediction of sea-level rise in Brazil. However, there are some regional observations for sea elevation rates in some coastal cities of Brazil that show annual rates of elevation varying from 0.002 to $0.0126 \mathrm{~m}$ between mid-twentieth century and early twenty-first century, as can be seen in Table 1.

Table 1 - Changes in mean sea level along the Brazilian coast.

\begin{tabular}{|c|c|c|c|}
\hline Author & Brazilian cities & $\begin{array}{c}\text { Variation rates } \\
\left(\mathrm{m} / \text { year }^{1}\right)\end{array}$ & Period \\
\hline \multirow[t]{4}{*}{ Pirazolli (1986) } & Recife (PE) & 0.0037 & \multirow{4}{*}{$\begin{array}{l}1950 \text { to } \\
1970\end{array}$} \\
\hline & Salvador (BA) & 0.0016 & \\
\hline & Canaveiras (BA) & 0.0031 & \\
\hline & Imbituba (SC) & 0.00055 & \\
\hline \multirow[t]{7}{*}{ Aubrey et al. (1988) } & Fortaleza (CE) & 0.00003 & \multirow{7}{*}{$\begin{array}{l}1950 \text { to } \\
1970\end{array}$} \\
\hline & Belém (PA) & 0.0034 & \\
\hline & Recife (PE) & 0.00002 & \\
\hline & Salvador (BA) & 0.0027 & \\
\hline & Canaveiras (BA) & 0.0041 & \\
\hline & $\begin{array}{c}\text { Rio de Janeiro } \\
(R J)\end{array}$ & 0.0036 & \\
\hline & Imbituba (SC) & 0.0007 & \\
\hline Silva (1992) & Rio de Janeiro & 0.0126 & $\begin{array}{l}1965 \text { to } \\
1986\end{array}$ \\
\hline Harari e Camargo (1994) & Recife (PE) & 0.0056 & $\begin{array}{c}1946 \text { to } \\
1988\end{array}$ \\
\hline $\begin{array}{c}\text { França (2000) and Mesquita } \\
(2003)\end{array}$ & $\begin{array}{l}\text { Atlântico } \\
\text { Equatorial }\end{array}$ & 0.004 & $\begin{array}{c}\text { Altimetric } \\
\text { data }\end{array}$ \\
\hline Lasada et al. (2013) & Salvador (BA) & 0.002 & $\begin{array}{l}1950 \text { to } \\
2009\end{array}$ \\
\hline \multicolumn{2}{|c|}{ Average of observations (m/year $\left.{ }^{1}\right)$} & \multicolumn{2}{|c|}{0.00318} \\
\hline
\end{tabular}

Adapted from PBMC (2017) 


\section{DYNAMICS OF MACROTIDAL IN AMMC}

Tides in the region are semidiurnal, with mean spring tide ranging around $3.3 \mathrm{~m}$ on the inner shelf, although significant amplification occurs inside estuaries and bays. The tidal range in Marajó Bay (Pará State/Brazil) is around $4.0 \mathrm{~m}$, while in São José Bay (Maranhão State/Brazil) it can reach $7.5 \mathrm{~m}$ (DHN, 2017). The tide wave is asymmetrical (shorter rising tides), but displays a sharp decrease of rising rates about 2 hours before high spring tides, when extensive intertidal areas become inundated (Souza-Filho, 2005). This pattern of tidal asymmetry can drive stronger ebb flows, as indicated in similar macrotidal estuaries (Lessa, 2000).

In the case study area, the environmental protection area of the Maranhão reentrances (see Fig. 1); there are 4 tidal events in $24 \mathrm{~h}$ (two low tide events and two high tide events). In this area, low tide events vary from 0 to 4 $\mathrm{m}$ and the events of high tides are usually above $5 \mathrm{~m}$. To exemplify, the Fig. 2 demonstrates the pattern of occurrence of low tide events and high tides for the year 2017 for São Luís, Maranhão (BRA), the data used come from the Hydrographic Center of the Brazilian Navy (to access the data: https://www.marinha.mil.br/chm/dados-do-segnav/dados-de-mare-mapa).

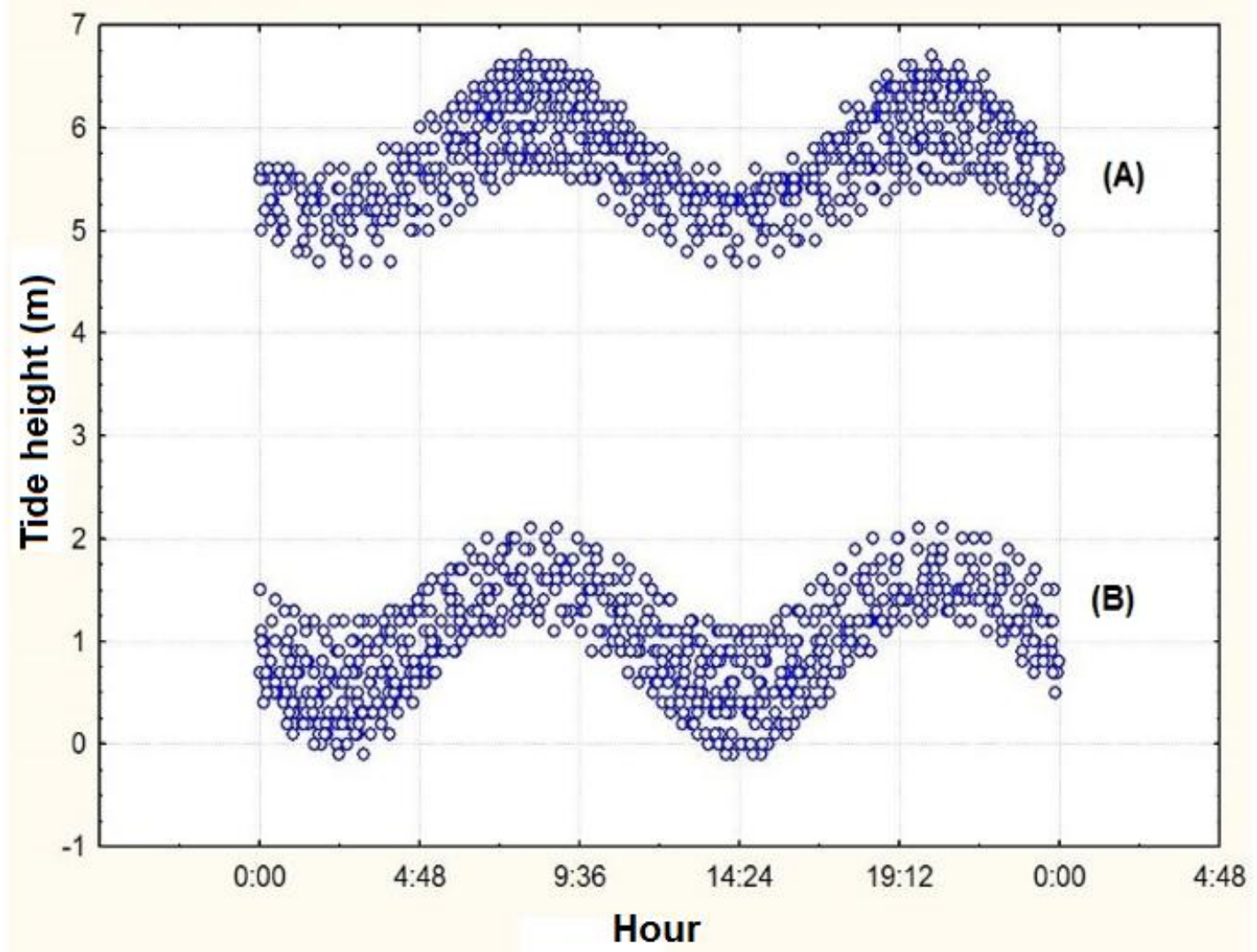

Figure 2 - Variation of the tide in the Port of Itagui (São Luís, MA - Brazil) ${ }^{1}$ for the year 2017. (A) - High tide events. (B) - Low tide events.

\footnotetext{
${ }^{1}$ Area belonging to AMMC.
} 


\section{MODELING EXPERIMENT (BR-MANGROVE)}

The model used in this paper (BR-MANGROVE) was prepared according to the theoretical precepts described by Brazilian research aimed at simulating the SLR impacts in mangrove (Bezerra et al., 2014), which developed a computer model to simulate mangrove ecosystem response to SLR. The model simulated the SLR for the study area in 90 (ninety) elevation steps, from $0.00318 \mathrm{~m}$ to $0.2862 \mathrm{~m}$, with an annual rate of elevation of $0.00318 \mathrm{~m}$ from 2010 to 2100 . Elevation rate adopted for the present study was $3.18 \mathrm{~mm} /$ year (00318m/year), this value corresponds to the average values of sea elevation observed in some Brazilian cities according to the PBMC (see Table 1).

The process of sea-level rise: we simulate a scenario of sea-level rise up to $0.2868 \mathrm{~m}$, distributed as an arithmetic progression of reason $0.00318 \mathrm{~m}$ ("i") over 90 intermediate elevation steps, as demonstrated in the equation (1):

\section{(1) - Sea-Level Rise = wc + (elevation step $x$ i)}

Where:

"Sea-level rise" is the value of sea-level rise in each water cell at current "elevation step";

"Elevation step" corresponds to the time step required for the sea-level rise. We consider that each elevation step is equivalent to one year;

"wc" is the value of water column (in meters) at current elevation step in each water cell; " $i$ " is a constant related to the sea-level rise increment whose the value is $0.2868 \mathrm{~m} /$ elevation step (year).

The water flux (Flux) corresponds to the displacement of water that occurs from a cell to another, this process originates from a water cell towards neighboring cells of any land cover class (mangrove cell, anthropic cell, terrestrial vegetation cell and beach cell) that have the altitude value lower than the sea-level rise, as expressed at equation (2):

\section{(2) Flux = Sea-level rise / neighboring cells,}

Where:

"Flux" corresponds to the value of "Sea-level rise" divided by the number of neighboring cells of each water cell.

The elevation of the sea can modify the sedimentation patterns of the material transported by the water column in estuarine environments (Cohen and Lara, 2003). For the simulation of vertical accretion of mud banks that can be colonized by the mangrove, we used equation (3) estimated by Alongi (2008).

$$
\text { (3) } Y=1.693+0.939 x
$$

Where:

- $\quad$ "Y" - values of vertical accretion of sediment in $\mathrm{mm}$.

- $\quad$ "X" - SLR values in $\mathrm{mm}$. 
Modeling procedures were carried out in order to simulate the following events: (i) sea level advancement over the continent; (ii) displacement of the tidal influence area (TIA); (iii) sediment longitudinal accretion (formation of new mud banks) in areas adjacent to the mangrove forests; (iv) changes in the extent of the mangrove areas and/or the mangrove resists to SLR; ( $v$ ) the impact of barriers to landward migration and the development of new mangrove areas. Below is a description of the elements in the BR-MANGROVE model:

- Original mangrove area - correspond to the existing mangrove extent in 2010 at the study area.

- Mangrove Decrease - correspond to the area of mangrove forest that is suppressed at each elevation step.

- Mangrove increase - correspond to the young mangrove areas that manage to migrate at each event of displacement of the TIA;

- Remaining mangrove area correspond to the original mangrove areas that are not affected by increased water column or the mangrove areas that are not affected by the SLR due to the high rates of sedimentation (horizontal and vertical).

The computational model was implemented using TerraME, a toolbox for spatially explicit modeling integrated with geospatial databases. TerraME supports cellular automata, agent-based models, and network models running in 2D cell spaces. TerraME provides an interface to the TerraLib geographical database, allowing models direct access to geospatial data. Its modelling language has built-in functions that makes it easier to develop multi-scale and multi-paradigm models for environmental applications (more information at http://www.terrame.org/doku.php). Our implementation is based on the cellular automata computational model, a logical system that has the concept of cell as the basic unit: each cell has a neighborhood of cells and a discrete state that may vary during the simulation, according to its transition rules (Wolfram 1983).

\section{DATABASE AND CELLULAR SPACE}

The geographic database and cellular space (Fig. 3) were created in a geographic information system developed by the National Institute for Space Research (INPE), the TerraView 4.2.0 (available at http://www.dpi.inpe.br/terraview/), with projection/datum: LatLong/WGS84. Adopting the spatial resolution of $1 \mathrm{~km}^{2}(1 \mathrm{~km} \times 1 \mathrm{~km})$, the study site was represented by a cellular space containing 20,603 cells (Fig. 3A). As a cellular automata system, each cell has, at a certain time, a unique state and a set of attributes that defines this state. During the simulation procedures, the states and attributes of every cell can change according to the transition rules. The initial state of the cell corresponds to the land cover classes (mangrove forest, water, terrestrial vegetation, developed areas $^{2}$, and others) at the initial time for year 2010 (Fig. 3B), and the attributes correspond to the soils and altimetry classes (Figs. 3C and 3D, respectively). The data used for the states and attributes comes from the official mapping conducted by the Brazilian Agricultural Research Corporation (EMBRAPA), and is available at the website of

\footnotetext{
${ }^{2}$ Areas occupied with human uses, where the original vegetation was removed
} 
the Ecological-Economic Zoning of the Maranhão State (https://www.cnpm.embrapa.br/projetos/macrozee/).
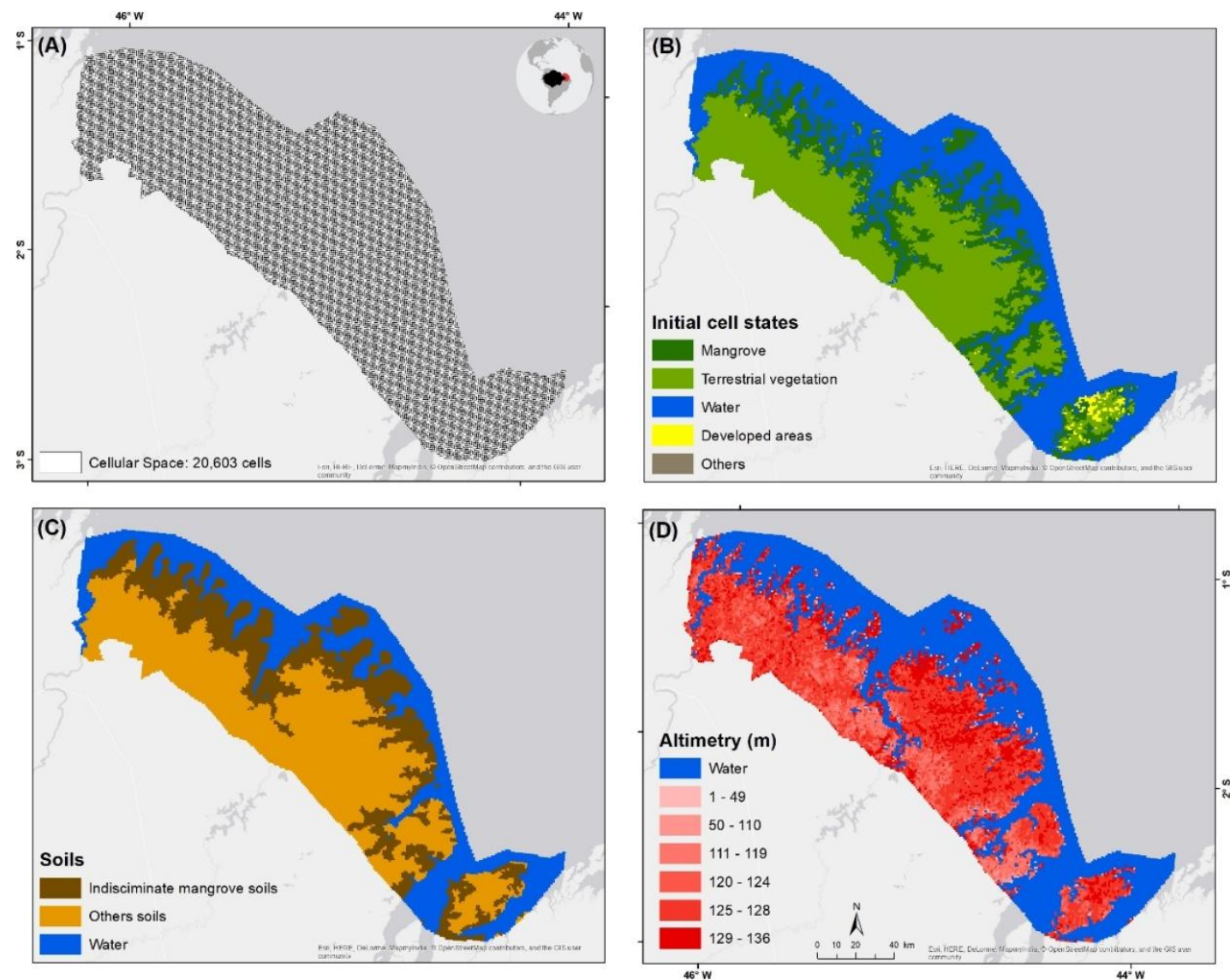

Figure 3 - (A) Empty cellular space (B); Initial cell state; (C) Soil attribute of the cells; (D) Altimetry attribute of the cells.

Initially, the cellular space was empty, with no geographic information in the database. To fill the cells with attribute values, we used the 'Fill cells' plugin in the TerraView software. The 'Fill Cells' plugin allows the calculation of attribute values of tables associated with cell type layers. The objective is to standardize information from various sources, in different formats (vector and raster data, in addition to other cell layers), by aggregating them in the same spatial-temporal base. It allows attributes from both dynamic and static tables to be calculated. Depending on the geometric representation and the semantics of the input data attributes, different operators can be applied. For this research, the 'majority class' operator was used. The cellular space was superimposed on the files with geographic information, and each cell assumed the geographic information that occupied most of the cell area. This procedure was used to determine the cells initial states and their soil and altimetry attributes. For the altimetry attribute, the final cell value was the calculated average of all altimetry values within each cell. 


\section{BR-MANGROVE RULES TRANSITION (MODEL CALIBRATION)}

The following are the specific rules used for calibration of the model:

1. Mangrove only exists in the area under tidal influence (ATI) (Faraco, AngretoFilho and Lana, 2010; Field, 1995; Spalding, Kainuma and Collins 2010);

2. The ATI is determined by the tidal range in the study area, that is, between low tide and high tide events;

3. Initially, the ATI value ranges from 2 to $5 \mathrm{~m}$ above the mean sea level, as indicated by Ferreira (1988) and validated by tide data from the oceanographic database of the Brazilian Navy (see Fig. 2). As sea-level rises, the value of ATI is updated by adding the sea level increments calculated by the model;

4. At every elevation step of sea-level rise, mangrove cells may migrate to adjacent cells since natural or artificial barriers for mangrove migration are not present on the ATI. In this case, cells of land cover class assigned as terrestrial vegetation are converted to mangrove cell (mangrove migration);

5. Cells of land cover class assigned as developed cells correspond to artificial barriers for mangrove migration. Conversely, natural barriers correspond to cells in which the altimetry attribute value is higher than the ATI, or the soil attribute is different than 'indiscriminate mangrove soil';

6. The mangrove inundation occurs when the height of the water column is greater than or equal to the altimetry of adjacent mangrove cells. In this case, mangrove cells change to water cells (mangrove inundation);

7. Cells classified as 'developed area' or 'terrestrial vegetation' can be inundated by the rising sea level. In this case, the inundation occurs when the height of the water column is greater than or equal to the altimetry of adjacent cells.

\section{RESULT}

This modelling exercise provides a vulnerability assessment of a portion of the eastern Amazonian mangrove forests to SLR, and their potential to migrate towards landward areas. Although we recognize the importance of other factors, such as changes to the local sedimentology and sediment supply (Gilman, Ellison and Coleman, 2007), changes in salinity resulting from hydrological adjustments to new water levels (Howard et al., 2015), and the species composition of the local mangrove forests (McKee, 2010), this vulnerability assessment is based solely on (1) sea-level rise relative to a static mangrove surface elevation, and (2) the existence of landward barriers, both natural and artificial.

In this study, the initial conditions for the model (corresponding to the year 2010) are: original mangrove, terrestrial vegetation, water, developed areas and bare soil. For this initial condition, the calculated mangrove area was $4,180 \mathrm{~km}^{2}$, which corresponds to $20.3 \%$ of the study area (Fig. $4 \mathrm{~A}$ ). 

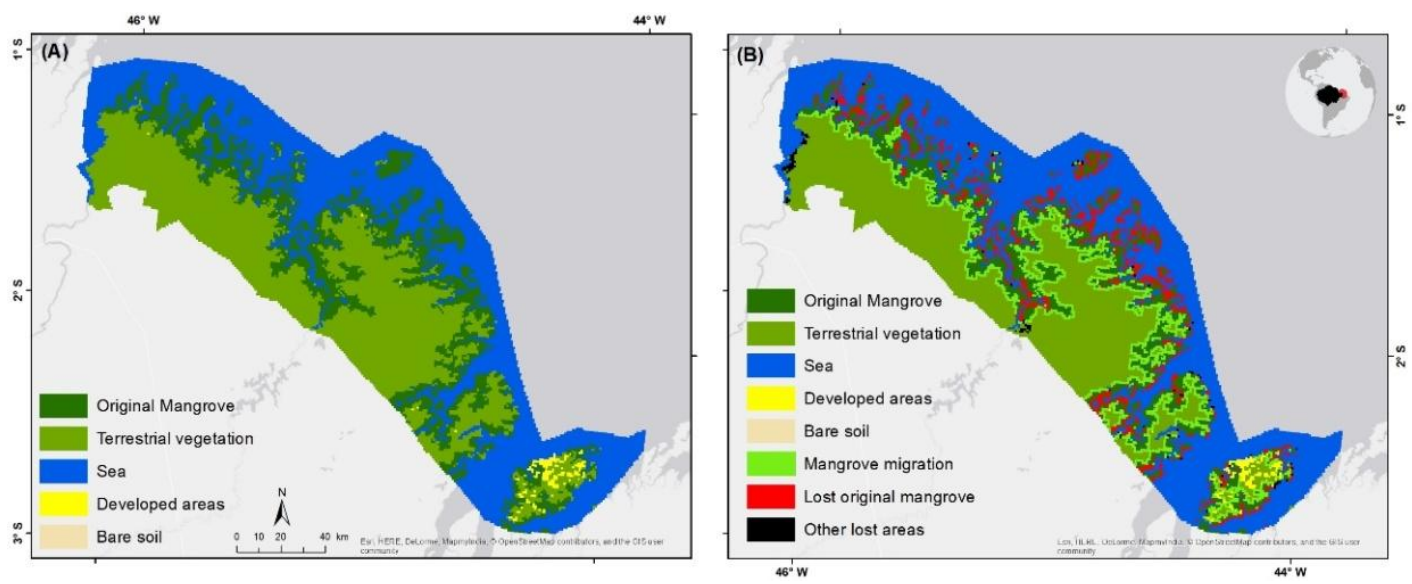

Figure 4 - Initial condition for the modeling exercise in the study area (based on data for the year 2010)

At the end of the simulation (year 2100), the original mangrove area was reduced to $2,916 \mathrm{~km}^{2}$, a loss of $30.24 \%$, compared to the initial mangrove extent of $4,180 \mathrm{~km}^{2}$. However, this loss of original mangrove area was compensated by extensive landward migration, which resulted in the addition of $1,585.4 \mathrm{~km}^{2}$ of new mangrove cover, following the modeled SLR. The study area presents favorable conditions for mangrove landward migration, since there are no significant anthropogenic barriers and no significant sediment inputs. In addition, the occurrence of macro-tides (with daily variations around $5 \mathrm{~m}$ ) produces migration corridors along the many existing stream channels, allowing mangroves to move upstream as sea level rises. Therefore, although the results of this modeling exercise indicate that there is a loss of the original mangrove area from the projected SLR, local conditions favors the expansion of new mangrove areas towards the continent (Fig. 4 B).

The total mangrove area at the end of the modeling exercise in 2100 presented a value of $4,481 \mathrm{~km}^{2}$ (original mangrove areas minus mangrove area lost to inundation plus new mangrove area from landward migration), which, when compared to the original mangrove area, indicates an increment of 301 $\mathrm{km}^{2}$ from the beginning to the end of the simulation. This corresponds to an increase in the total mangrove area of $7.2 \%$, indicating that events of SLR can derive a positive impact on eastern Amazonian mangroves.

The results of present study suggest that the Amazonian mangroves are very resilient, and their adaptive capacity to SLR appears to be large, as observed in similar tidal-dominated systems elsewhere (Alongi 2009; Twilley and Day 2012; Kirwan and Megonigal 2013). These mangroves are able to migrate vertically and horizontally, keeping pace with SLR by directly or indirectly influencing soil accretion processes through the production and accumulation of organic matter, as well as the trapping and retention of mineral sediment. Organic matter accumulation and its contribution to soil formation is widely recognized, and the processes controlling it has been well studied in many habitats. A study showed that the relative contribution of organic solids to surface accretion in Caribbean mangroves was one to three times that of inorganic solids across study sites (McKee 2010). This study also pointed to biological, rather than mineral controls on vertical accretion. Physical processes 
also contribute to mangrove vertical accretion, including inorganic sedimentation, groundwater influx (causing soil swelling) and deep land movements - such as geological uplift or glacial isostatic rebound (Krauss, McKee and Lovelock, 2014).

Landward migration has also been observed in other modeling studies. Alternative future sea-level rise and urbanization scenarios were used to map landward migration of tidal saline wetlands along the Gulf of Mexico, and to identify locations where barriers may prevent such migration, and how existing protected lands might accommodate expected landward migration (Enwright, Griffith, Osland 2016). In Brazil, in the year 2014 was published the first Brazilian research aimed at simulating the SLR impacts in mangrove areas for the 21st century (Bezerra et al., 2014). The study focused on the Island of Maranhão, and the authors concluded that human occupation intensifies the negative impacts of the SLR, since they act as a barrier preventing the landward migration of the mangrove. In the AMMC was used radar data to map the dynamics of expansion and retraction in Amazonian mangrove forests (Nascimento et al., 2013). This research showed that, between 1996 and 2008, the mangrove experienced a loss of $14 \%\left(1212.50 \mathrm{~km}^{2}\right)$ of original area, and an expansion of $22 \%\left(1931.04 \mathrm{~km}^{2}\right)$ due to landward migration (Fig. 5), resulting in a net increase of the mangrove area of about $718.54 \mathrm{~km}^{2}$, a $10.7 \%$ increase. The authors suggest that a high sedimentation rate was the main factor responsible for the observed increase. The PBMC, in their 2013 report, indicate that, in addition to SLR, climate change can affect coastal dynamics and sedimentation rates, which may promote expansion of mangrove areas (PBMC, 2013). 

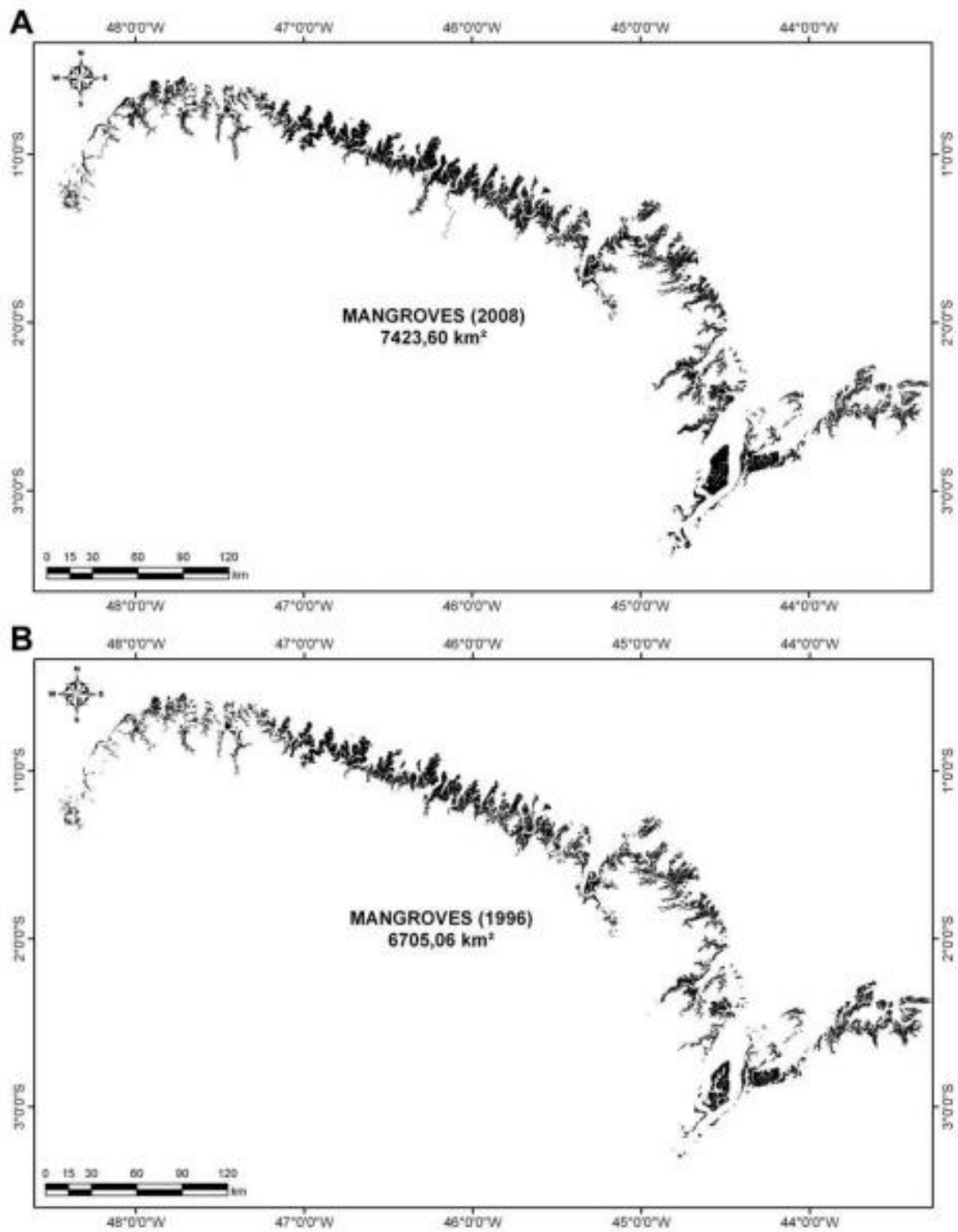

Figure 5 - Changes in the extent of mangrove forests in the AMMC using radar data: (A) Mangrove area in 2008, (B) Mangrove area in 1996. Modified from Nascimento et al. (2013).

Other Brazilian researchers using robust methodological procedures for identifying changes in mangrove area coverage have observed similar patterns. For example, a study used a combination of GIS and remote sensing techniques to analyze a 25-year time series of radar and satellite images, aiming to identify changes in mangrove coverage along a section of the central Amazon coastline (Cohen and Lara, 2003). In this study was concluded that mangrove stands were migrating landward, possibly as a response to relative sea level rise, and that this migration was limited by local topography. A literature review on the mangrove ecosystem response to climate change in the last 25 years and concluded that the mangroves of southeastern Brazil present patterns of expansion to the continent consistent with the sea-level rise impacts described in the scientific literature (Godoy and Lacerda 2015; PBMC, 2017). For example, 
studies indicate that some areas of mangroves in northeast Brazil showed an increase of $400 \%$ between 1993 and 2008.

Although SLR have been mentioned in these studies as a possible factor in the observed changes in mangrove area coverage, these authors point out to the peculiar coastal dynamics (erosion, progression, etc.) and to the influence of local land use and occupation as the main causes for the observed expansion/retraction patterns. The uncertainty on the impacts of SLR in Brazilian mangroves results from the inexistence of an orthometric reference for the coastal zone, and the lack of historical sea level data that allows the establishment of specific rates of elevation for the Brazilian coast (Godoy and Lacerda, 2015).

\section{FINAL CONSIDERATIONS}

The results presented here suggest that mangrove forests in the AMMC may present a pattern of migration to the continent and show a net gain of area ( $7.2 \%$ increase in mangrove area) for potential SLR events. These mangroves can use existing tidal channels to migrate landward into the continent, as sea level rises, and thus colonize areas of terrestrial vegetation or other areas that allow the colonization of the mangrove. Another factor that corroborates the pattern of mangroves migration observed in the simulation is the small influence of human occupations in the AMMC, as well as, the presence of macrotides that can amplify the effects of SLR. Based on these findings, Brazilian public policies for preservation of areas adjacent to Amazonian mangroves should be intensified, focusing on the identification of migration corridors for the mangroves and the development of adaptation strategies in face of impending sea-level rise. In this context, new studies should be developed that identify areas with potential to be colonized by mangroves in different scenarios of SLR in the AMMC.

The Amazonian mangroves comprise the largest continuous area of mangroves in the world, and provide numerous environmental services to the coastal zone (nursery for marine life, a precious stock of blue carbon, and coastline protection to extreme climatic events). Therefore, it is vital to promote a better understanding of their response patterns to SLR events and other impacts of climate change, and to promote landscape-scale conservation plans that will enable these unique ecosystems to migrate both vertically and horizontally in response to future SLR.

\section{REFERENCES}

ALONGI, D.M. Resilience of mangrove forests, tsunamis, and global climate change. Estuarine, Coastal and Shelf Science, v. 76, n. 1, Publisher Elsevier, p. 1-13 (2008). doi:10.1016/j.ecss.2008.08.024.

ALONGI, D.M. The energetics of mangrove forests. New York, NY, USA: Springer (2009).

AUBREY, D.G. ET AL. Changing Coastal levels of South America in the Caribbean region from tide-gauge records. Tecconophys, 154:269-284 (1998). 
BEZERRA, D.S.; AMARAL, S.; KAMPEL, M. Impactos da elevação do nível médio do mar sobre o ecossistema manguezal: a contribuição do sensoriamento remoto e modelos computacionais. Ciência e Natura, 35(2): 152-162 (2013).

BEZERRA, D.S.; AMARAL, S.; KAMPEL, M.; ANDRADE, P.R. Simulating Sea-Level Rise Impacts on Mangrove Ecosystem adjacent to Anthropic Areas: the case of Maranhão Island, Brazilian Northeast. Pan-American Journal of Aquatic Sciences. 9(3): 188-198 (2014).

BOUILLON, S., BORGES, A.V., CASTAÑEDA-MOYA, E., DIELE, K., DITTMAR, T., DUKE, N.C., KRISTENSEN, E., LEE, S.Y., MARCHAND, C., MIDDELBURG, J.J., RIVERA-MONROY, V.H., SMITH III, T.J., TWILLEY, R.R. Mangrove production and carbon sinks: a revision of global budget estimates. Global Biogeochemical Cycles, 22: GB003052 (2008).

COHEN, M.C.L., LARA, R.J. Temporal changes of mangrove vegetation boundaries in Amazonia: application of GIS and remote sensing techniques. Wetlands Ecology and Management, 11: 223-231 (2003).

DANTAS, S.T.P.L., AMARO, V.E., COSTA, B.C.P. Mangrove reforestation as a mesotidial coastal protection and clean develepment mechanism on MacauSerra oil field, Potiguar Basin, Northeast Brazil. Journal of Coastal Research, SI 64: 1268-1271 (Proceedings of the 11th International Coastal Symposium, Szczecin, Poland) (2011).

DHN. Previsão de Marés. Departamento de Hidrografia e Navegação, Marinha do Brazil. Available at: http://www.mar.mil.br/dhn/chm/box-previsaomare/tabuas/index.htm. (2017)

DITTMAR, T., HERTKORN, N., KATTNER, G., LARA, R.J. Mangroves, a major source of dissolved matter sources to the oceans. Global Biogeochemical Cycles, 20: GB002570 (2006).

ENWRIGHT, N.M., GRIFFITH, K.T., OSLAND, M.J. Barriers to and opportunities for landward migration of coastal wetlands with sea-level rise. Frontiers in Ecology and the Environment, 14(6): 307-316 (2016).

FARACO, L.F.D., ANGRETO-FILHO, J.M., LANA, P.C. Methodology for assessing the vulnerability of mangroves and fisherfolk to climate change. Pan-American Journal of Aquatic Sciences, 5(2): 205-223 (2010).

FRANCA, C.A.S. Contribuição ao Estudo da Variabilidade do Nível do Mar na Região Tropical Atlântica por Altimetria por Satélite TOPEX/POSEIDON e Modelagem Numérica. Ph. Thesis, São Paulo, 274 p, (2000).

FERREIRA, H.O. Contribuição ao estudo das correntes de maré dos estreitos dos coqueiros e mosquitos, Maranhão. Boletim LaboHidro, 8: 45-59 (1988).

FIELD, C. Impacts of expected climate change on mangroves. Hydrobiologia, 295: 75-81 (1995).

FONTES, N.A., MORAES, C.A., COHEN, M.C.L., ALVES, I.C.C., FRANCA, M.C., PESSENDA, L.C.R., FRANCISQUINI, M.I., BENDASSOLLI, J.A., MACARIO, K., MAYLE, F. The impacts of the middle Holocene high sea-level stand and climatic changes on mangroves of the Jucurucu River, southern Bahia - NE Brazil. Radiocarbon, 59(1): 215-230 (2017). 
FRANCA, M.C., ALVES, I.C.C., COHEN, M.C.L., ROSSETTI, D.F., PESSENDA, L.C.R., GIANNINI, P.C.F., LORENTE, F.L., BUSO, A.A., BENDASSOLLI, J.A., MACARIO, K. Millennial to secular time-scale impacts of climate and sea-level changes on mangroves from the Doce River delta, Southeastern Brazil. Holocene, 26(11): 1733-1749 (2016).

GILLIS, L.G., BOUMA, T.J., JONES, C.G., VAN KATWIJK, M.M., NAGELKERKEN, I., JEUKEN, C.J.L., HERMAN, P.M.J., ZIEGLER, A.D. Potential for landscape-scale positive interactions among tropical marine ecosystems: a review. Marine Ecology Progress Series, 503: 289-303 (2014).

GILMAN, E., ELLISON, J., COLEMAN, R. Assessment of mangrove response to projected relative sea-level rise and recent historical reconstruction of shoreline position. Environmental Monitoring and Assessment, 124 (1): 105-130 (2007).

GODOY, M.D.P.; LACERDA, L.D. Mangroves Response to Climate Change: A Review of Recent Findings on Mangrove Extension and Distribution. An Acad Bras Cienc, 87 (2) (2015).

GREEN, E.P., MUMBY, P.J., EDWARDS, A.J., CLARK, C.D., (ED. A. J. EDWARDS). Remote Sensing Handbook for Tropical Coastal Management. Coastal Management Sourcebooks 3, UNESCO, Paris. 316 pp (2000).

GUO, M., LI, J., SHENG, C., XU, J., WU, L. A Review of Wetland Remote Sensing. Sensors, 17(4): 777 (2017).

HARARI, J.F.; CAMARGO, R. Tides and mean sea level variabilities in Santos (SP), 1944 to 1989. Internal Report of the Oceanographic Institute of the University of Sao Paulo, Sao Paulo, Brazil, no 36, (1995), 15 p.

HELD, A., TICEHURST, C., LYMBURNER, L., WILLIAMS, N. High resolution mapping of tropical mangrove ecosystems using hyperspectral and radar remote sensing. International Journal of Remote Sensing, 24: 2739-2759 (2003).

HEUMANN, B.W. Satellite remote sensing of mangrove forests: recent advance and future opportunities. Progress in Physical Geography, 35: 87-108 (2011).

HOWARD, R.J., KRAUSS, K.W., CORMIER, N., DAY, R.H., BIAGAS, J., ALLAIN, L. Plant-plant interactions in a subtropical mangrove-to-marsh transition zone: effects of environmental drivers. Journal of Vegetation Science, 26: 1198-1211 (2015).

HUNTINGTON, T.G. Evidence for intensification of the global water cycle: Review and synthesis. Journal of Hydrology, 319: 83-95 (2006).

IPCC. Climate Change 2013: the physical science basis. Contribution of working group 1 to the fifth assessment report of the inter-governmental panel on climate change (Stocker, T.F., D. Qin, G.K. Plattner, M. Tignor, S.K. Allen, J. Boschung, A. Nauels, Y. Xia, V. Bex, and P.M. Midgley [eds.]). Cambridge, United Kingdom and New York, NY, USA, 1535pp (2013).

Kathiresan, K., Bingham, B.L. Biology of mangroves and mangrove ecosystems. Advances in Marine Biology, 40: 81-251 (2001).

KIRWAN, M.L., MEGONIGAL, J.P. Tidal wetland stability in the face of human impacts and sea-level rise. Nature, 504: 53-60 (2013). 
KRAUSS, K.W., MCKEE, K.L., LOVELOCK, C.E., CAHOON, D.R., SAINTILAN, N., REEF, R., CHEN, L. How mangrove forests adjust to rising sea level. New Phytologist, 202: 19-34 (2014).

KUENZER, C., BLUEMEL, A., GEBHARDT, S., QUOC, T.V., DECH, S. Remote sensing of mangrove ecosystems: a review. Remote Sensing, 3: 878-928 (2011).

LACERDA. L. D.; MENEZES, M.O.T AND MOLISANI, M.M. Changes in mangrove extension at the Pacoti River estuary, $C E, N E$ Brazil due to regional environmental changes between 1958 and 2004. Biota Neotropica, 7(3): 67-72 (2007).

LOSADA, I.J. ET AL. Long-term changes in sea-level components in Latin America and the Caribbean. Global and Planetary Change, 104:34-50. 2013. doi: 10.1016/j.gloplacha.2013.02.006.

LESSA, G.C. Morphodynamic controls on vertical and horizontal tides - field results from two macrotidal shallow estuaries: central Queensland, Australia. Journal of Coastal Research, 16: 976-989 (2000).

MANSON, R.A., LONERAGAN, N.R., SKILLETER, G.A., PHINN, S.R. An evaluation of the evidence for linkages between mangroves and fisheries: a synthesis of the literature and identification of research directions. Oceanography and Marine Biology: An Annual Review, 43: 483-513 (2005).

MARTINELLI, L.A., VICTORIA, R.L., DEVOL, A.H., FORSBERG, B.R. Suspended Sediment Load in the Amazon Basin: An Overview. GeoJournal, 19(4): 381-389 (1989).

MAZDA, Y., WOLANSKI, E., RIDD, P.V. The Role of Physical Processes in Mangrove Environments: Manual for the Preservation and Utilization of Mangrove Ecosystems. Terrapub, Tokyo, 598 pp (2007).

MCKEE, K.L. Biophysical controls on accretion and elevation change in Caribbean mangrove ecosystems. Estuarine, Coastal and Shelf Science, 91: 475-83 (2010).

MCKEE, K. L., CAHOON, D. R., FELLER, I. C.. Caribbean mangroves adjust to rising sea level through biotic controls on change in soil elevation. Global Ecology \& Biogeography, 16: 545-556 (2007).

MESQUITA, A.R. Sea Level Variations Along the Brazilian Coast: A Short Review. Journal of Coastal Research, 35:21-31 (2003).

MILLIMAN, J.D., BARRETO, H.T. Relict magnesian calcite oolite and subsidence of Amazon Shelf. Sedimentology, 22: 37-145 (1975).

MORAES, B.C., COSTA, J.M.N., COSTA, A.C.L., COSTA, M.H. Variação espacial e temporal da precipitação no Estado do Pará. Acta Amazônica, 35(2): 207-214 (2005).

NASCIMENTO, W.R.JR., SOUZA-FILHO, P.W.M., PROISY, C., LUCAS, R.M., ROSENQVIST, A. Mapping changes in the largest continuous Amazonian mangrove belt using object-based classification of multisensor satellite imagery. Estuarine, Coastal and Shelf Science, 117: 83-93 (2013). 
NICHOLLS, R.J. Coastal flooding and wetland loss in the 21st century: changes under the SRES climate and socio-economic scenarios. Global Environmental Change, 14: 69-86 (2004).

PBMC. Impacto, vulnerabilidade e adaptação das cidades costeiras brasileiras às mudanças climáticas. Relatório especial do Painel Brasileiro de Mudanças Climáticas (PBMC), (2017), 184 p.

PESSENDA, L.C.R., VIDOTTO, E., DE OLIVEIRA, P.E., BUSO, A.A., JR., COHEN, M.C.L., ROSSETTI, D.D.F., RICARDI-BRANCO, F., BENDASSOLLI, J.A. Late Quaternary vegetation and coastal environmental changes at Ilha do Cardoso mangrove, southeastern Brazil. Palaeogeography, Palaeoclimatology, Palaeoecology, 363: 57-68 (2012).

PIRAZOLLI, PA. Secular trend of relative sea level (RSL) changes indicated by tide-gauge recoast, J Coast Res SI: 1, 1-26. (1986).

PURNAMASAYANGSUKASIH, P.R., NORIZAH, K., ISMAIL, A.A.M., SHAMSUDIN, I. $A$ review of uses of satellite imagery in monitoring mangrove forests. IOP Conference Series: Earth and Environmental Science, 37: 012034 (2016).

ROG, S.M., CLARKE, R.H., COOK, C.N. More than marine: revealing the critical importance of mangrove ecosystems for terrestrial vertebrates. Diversity and Distributions, 23(2): 221-230 (2017).

SANTOS, L.C.M., BITENCOURT, M.D. Remote sensing in the study of Brazilian mangroves: review, gaps in the knowledge, new perspectives and contributions for management. Revista de Gestão Costeira Integrada - Journal of Integrated Coastal Zone Management, 16(3): 245-261 (2016).

SCHAEFFER-NOVELLI, Y., CINTRÓN-MOLERO, G., SOARES, M.L.G., DE-ROSA, T. Brazilian Mangroves. Aquatic Ecosystem Health and Management, 3(4): 561570 (2000).

SOARES, M.L.G. A conceptual model for responses of mangrove forest to sea level rise. Journal of Coastal Research, SI 56: 267-271 (2009).

SOUZA-FILHO, P.W.M. Costa de macromaré da Amazônia: Cenários morfológicos, mapeamento e quantificação de áreas usando dados de sensores remotos. Revista Brasileira de Geofísica, 23(4): 427-435 (2005).

SOUZA-FILHO, P.W.M., LESSA, G.C., COHEN, M.C.L., COSTA, F.R., LARA, R.J. The subsiding macrotidal barrier estuarine system of the Eastern Amazon coast, Northern Brazil. In: Dillenburg SF, Hesp PA (eds) Geology and geomorphology of Holocene coastal barriers of Brazil, 1st ed. Springer, New York, pp 347-376 (2009).

SPALDING, M., KAINUMA, M., COLLINS, L. World Atlas of Mangroves. London, UK: Earthscan. 336 pp (2010).

TWILLEY, R.R., DAY, J.W. MANGROVE WETLANDS. IN: DAY, J.W., CRUMP, B.C., KEMP, M.W., YÁÑEZ-ARANCIBIA, A. (Eds). Estuarine ecology. Hoboken, NJ: John Wiley \& Sons (2012).

WELLS, S., RAVILIOUS, C., CORCORAN, E. In the Front Line: Shoreline Protection and Other Ecosystem Services from Mangroves and Coral Reefs. UNEP-WCMC Biodiversity Series 24. Cambridge, UK: UNEP-WCMC, 44 pp (2006). 
WOLFRAM, S. Statistical mechanics of cellular automata. Reviews of Modern Physics, 55(3): 601-644 (1983).

ZEMBRUSCKI, S.G., GORINI, M.A., PALMA, J.J.C., COSTA, M.P.A. Fisiografia e distribuição dos sedimentos superficiais na Plataforma Continental Norte Brasileira. Boletim Técnico da Petrobras, 14: 127-155 (1971). 